\title{
Parkinson's Disease: Carbidopa, Nausea, and Dyskinesia [Retraction]
}

\section{Hinz M, Stein A, Cole T. Clin Pharmacol. 2014;6:189-194.}

The Editor-in-chief and Publisher of Clinical Pharmacology: Advances and Applications wish to retract the published article.

This perspective article cites several original research articles published by the authors, which have recently been retracted. This article draws on the findings from those original research articles to form central arguments and discussion, and as a result of the research articles' retraction, the argument presented in this article is no longer valid and the editor has determined it should be retracted.

Our decision-making was informed by our policy on publishing ethics and integrity and the COPE guidelines on retraction.

The retracted article will remain online to maintain the scholarly record, but it will be digitally watermarked on each page as "Retracted".

\section{Publish your work in this journal}

Clinical Pharmacology: Advances and Applications is an international, peer-reviewed, open access journal publishing original research, reports, reviews and commentaries on all areas of drug experience in humans. The manuscript management system is completely online and includes a very quick and fair peer-review system, which is all easy to use. Visit http://www.dovepress.com/testimonials.php to read real quotes from published authors. 